DOI: 10.20472/TEC.2019.008.015

\title{
KITTISAK LAKSANA
}

Curriculum and Instruction Department, Faculty of Education, Ramkhamhaeng University, Thailand

KANRAWEE BUSAYANON

Curriculum and Instruction Department, Faculty of Education, Ramkhamhaeng University, Thailand

\author{
YASA MAHAMARN
}

Curriculum and Instruction Department, Faculty of Education, Ramkhamhaeng University, Thailand

\section{CREATING PRE-SERVICE TEACHERS' ENGAGEMENT IN AN ACTIVE LEARNING JOURNEY WITH PROJECT-BASED LEARNING TO BECOME EFFECTIVE TEACHERS}

\begin{abstract}
:
A primary goal of teacher preparation programs is to develop pre-service teachers' ability in applying the teaching knowledge and skills they learn in real classrooms in varying community, school, and classroom contexts. Upon developing these abilities, pre-service teachers can help their students successfully acquire knowledge. The present study aims to investigate the extent to which project-based instruction can enhance the ability to develop teaching materials among pre-service Social Studies teachers currently studying at an open-admission university in Thailand. The same subjective test was administered to a sample of 30 participants before and after the study and was scored using an analytic rubric. The pre-test and post-test data were analyzed via a paired sample t-test, which revealed that participation in project-based instruction resulted in the pre-service Social Studies teachers' improved ability to develop teaching materials, both overall and for each specific criterion, at a statistical significance level of .01.
\end{abstract}

\section{Keywords:}

Instructional media, pre-service teachers, project-based learning, social studies

JEL Classification: 129 


\section{Introduction}

The National Education Act, B.E. 2542 (A.D. 1999) had a major and multifaceted influence on education in Thailand. A major change was related to teacher development and the production of quality teachers. With such a change, professional organizations are responsible for establishing standards and code of ethics for the teaching profession, specifying the process of teacher production, enhancing teacher quality, and setting mandated requirements and regulations for teacher licensure. To comply with the teacher licensing regulations, teachers must obtain a teaching license to become eligible to teach in schools. Since the Thai government acknowledges and realizes the importance of teachers, there are strong government intentions to professionalize the teaching profession in Thailand and put forth their best efforts in making the aforementioned changes possible. Various studies show how teachers play a crucial role in society, which indicate that teacher quality has major effects on the quality of learners (Canales \& Maldonado, 2018; Darling-Hammond, 2000; Lyublinskaya \& Tournaki, 2011).

Teachers are therefore an important factor contributing to education quality, as well as student learning achievement and their continued success. For this reason, the Teachers' Council of Thailand established the regulation of the Teachers' Council of Thailand on professional standards B.E. 2556 (A.D. 2013), requiring teachers to possess knowledge and professional teaching experience as follows: 1) Professional teacher; 2) Educational philosophy; 3) Language and culture; 4) Psychology for teachers; 5) Curriculum development; 6) Learning management and classroom management; 7) Research for learning development; 8) Instructional innovation and information technology; 9) Learning measurement and evaluation; 10) Quality assurance in education; and 11) Morality, ethics, and code of ethics (Teachers' Council of Thailand, 2015).

Education faculties are the leading organizations which offer teacher preparation programs to produce quality teachers. Their primary objective is to prepare pre-service teachers for the teaching profession by developing their educational wisdom and intellectual capacities for teaching. To become an effective teacher, pre-service teachers must be capable of applying the knowledge and skills they learn and acquire in real classrooms in varying community, school, and classroom contexts. They must also be versed in best practices for integrating appropriate teaching methodologies for the subject content and deliver instructions effectively.

Given that pre-service teachers must maximize their professional development, the Innovation in Social Studies Teaching course is carefully designed to develop their knowledge of learning management and classroom management, in addition to 
instructional innovation and information technology in the field of Social Studies. The course emphasizes on developing knowledge of Technological Pedagogical Content Knowledge (TPACK) to enhance student learning experiences (Royal Society, 2015). Specifically, pre-service teachers must be able to combine three primary knowledge components: content knowledge (CK); pedagogical knowledge (PK); and technological knowledge (TK) to enable them to effectively and efficiently integrate technology with teaching in specific subjects (Koehler \& Mishra, 2009).

Subsequently, the researcher employed the project-based learning ( $\mathrm{PjBL}$ ) approach in the Innovation in Social Studies Teaching course, with the primary objective of investigating the extent to which project-based instruction can enhance the ability to develop teaching materials among pre-service Social Studies teachers currently studying at an open-admission university in Thailand. It was hypothesized that after participating in the PjBL instruction, the pre-service Social Studies teachers would achieve higher mean scores for the ability to develop teaching materials.

\section{Literature Review}

Hofer and Grandgenett (2012) pointed out that assigning pre-service teachers to conduct some activities in courses related to instructional technology or innovation is a possible way of developing their TPACK skills. In the present study, the researcher selected project-based learning $(\mathrm{PjBL})$ as a teaching approach. The approach promotes student engagement through: 1) Stimulating students' curiosity with authentic, real-life situations; 2) Designing a preliminary plan for the project; 3) Discussing and collecting useful and necessary information for the project; 4) Establishing absolute criteria for assessing projects; 5) Gathering all the materials and equipment needed for the project; 6) Creating projects; 7) Preparing project presentations; 8) Giving a presentation; and 9) Doing self-reflections on the work processes and a self-assessment of their own project using the formulated criteria (Stik \& Hrbek, 2006).

In $\mathrm{PjBL}$, instead of listening to the lecture and passively receiving knowledge from the teacher, students play a key role in finding out more information about the topics to fill gaps in their knowledge. Further, students work alongside the teacher to complete the project, and then a presentation is given after the project is accomplished. The teacher's role is to pose driving questions that motivate them in their learning and drive selfdirected inquiry and to facilitate the arrangement of learning experiences for learners (Bell, 2010). The basic aspects of PjBL are as follows: 1) What students want to learn (a need to know); 2) Use questions to drive self-directed inquiry; 3) Listen to students' needs and allow them to decide and select what they want to learn; 4) Promote studentcentered learning environment; 5) Provide meaningful hands-on experience; 6) Focus on outcome-based learning; 7) Have an intense desire to touch the students' lives and 
understand things present in their world, leading to new innovations; 8) Encourage learning with in-depth understanding rather than by memorizing concepts; 9) Focus on the transfer of learning; 10) Promote social and collaborative skills; and 11) Provide feedback and suggestions for improvements (Bell, 2010; Larmer, Mergendoller, \& Boss, 2010; Saye, 2017; Schultz, 2010).

Many relevant studies point to $\mathrm{PjBL}$ as a suitable teaching method for maximizing both pre-service teachers' and in-service teachers' professional development (Howard, 2002). Specifically, PjBL promotes academic knowledge, professionalism, and the application of knowledge (García, 2016). Furthermore, it also strengthens teachers' ability to create learning materials (Özdamli, 2011). A majority of teachers reported that $\mathrm{PjBL}$ instruction benefit their students by allowing them to develop self-regulated learning skills, individual accountability, and social skills. Moreover, it also promotes positive relationships between teachers and learners and enhances teachers' professional skills (Lasauskiene \& Rauduvaite, 2015).

\section{Methodology}

Of the population of 66 pre-service Social Studies teachers enrolled in the Innovation in Social Studies Teaching course in the 2018 academic year at an open-admission university in Thailand, a sample of 30 was selected through a simple random sampling approach. The students that were selected to participate in the present quasiexperimental research were required to take a pre-test and a post-test. The researcher manipulated the project-based instruction as an independent variable and measured its effects on pre-service Social Studies teachers' ability to develop teaching materials.

The content utilized in the study included the use of media and innovations in Social Studies teaching, including e-books, infographics, educational games, VDO clips, a flipped classroom, WebQuest, computer-assisted instruction, mobile learning, and elearning. PjBL lesson plans for 22 teaching hours were created, with the content validated by three experts in either Social Studies or material development. The three experts were requested to complete an evaluation form to indicate how far they agreed with the statements in terms of accuracy, appropriateness, and relevance of the components included in the lesson plan. The results reveal that the PjBL lesson plans contained highly accurate, appropriate, and relevant components $(M=4.85)$.

To assess the pre-service teacher's abilities at developing teaching materials, the researcher developed an analytic rubric based upon Payne (2003), Cennamo, Ross, and Ertmer (2010), and Harris, Grandgenett, and Hofer (2010). The analytic rubric consisted of five criteria: 1) design; 2) content relevance to the context and target learners; 3) encouraging student engagement in the learning process; 4) content accuracy and appropriateness; and 5) the integration of content, pedagogy, and 
technology. The rubric had a five-point scoring scale (1 Lack of Achievement, 2 Insufficient Achievement, 3 Adequate Achievement, 4 Proficient Achievement, and 5 Excellent Achievement). The narrative descriptions for each criterion at each performance level indicated what the students were expected to perform to achieve each score, with the total score out of 25 points.

Next, the three experts were provided with an Item-Objective Congruence (IOC) Index form to complete so that they could verify whether the five criteria on the rubric were relevant to the narrative descriptions of each criteria and performance score. All three experts rated a high degree of congruence $(+1)$ on every item on the IOC form, which guaranteed that the rubric measured what it was intended to measure, with an IOC value of 1.0. Additionally, a pilot study was conducted with 30 pre-service teachers who shared similar characteristics with the participants that were to participate in the main study. After administering the pilot test, the researcher provided two assessors with the developed rubric. Inter-rater reliability was undertaken to measure the level of agreement between the two raters with respect to data interpretation. The results reveal an acceptable level of internal consistency, with Cronbach's a coefficient values of .785 at a statistical significance level of .01 .

During the data collection, a single sample group was pre-tested and post-tested with the same subjective test. The data were analyzed using descriptive statistics, such as the mean score and standard deviation. In addition, the pre-test and post-test data were compared using inferential statistics for paired-sample t-test to measure the extent to which the pre-service Social Studies teachers' abilities to develop teaching materials had improved after participating in the project-based instruction.

\section{Findings}

This section presents the findings regarding the extent to which the project-based instruction enhanced the pre-service Social Studies teachers' abilities to develop teaching materials (Table 1).

Table 1. Pre-test and post-test means, standard deviations, and paired-sample T-Test on the pre-service Social Studies teachers' abilities to develop teaching materials

\begin{tabular}{lccccc}
\hline \multicolumn{1}{c}{ Criteria } & $\begin{array}{c}\text { Pre-test } \\
\boldsymbol{M}(\text { SD) }\end{array}$ & $\begin{array}{c}\text { Post-test } \\
\boldsymbol{M}(\mathbf{S D})\end{array}$ & t & df & p \\
\hline $\begin{array}{l}\text { 1) Design } \\
\text { 2) Content relevance to the context and }\end{array}$ & $2.67(0.48)$ & $4.00(0.83)$ & $-26.655^{*}$ & 29 & .000 \\
$\begin{array}{l}\text { target learners } \\
\text { 3) Encouraging student engagement in }\end{array}$ & $2.33(0.59)$ & $3.83(0.70)$ & $-26.492^{*}$ & 29 & .000 \\
$\begin{array}{l}\text { the learning process } \\
\text { 4) Content accuracy and }\end{array}$ & $2.67(0.48)$ & $4.50(0.51)$ & $-14.367^{*}$ & 29 & .000 \\
$\begin{array}{l}\text { appropriateness } \\
\text { 5) The integration of content, } \\
\text { pedagogy, and technology }\end{array}$ & $2.00(0.00)$ & $4.33(0.48)$ & $-26.655^{*}$ & 29 & .000
\end{tabular}


Table 1 reveals higher post-test scores for abilities to develop teaching materials ( $M=$ $20.67, S D=1.83)$ compared to the pre-test scores $(M=10.67, S D=1.52)$. In addition, the pre-test and post-test results show that the pre-service Social Studies teachers' abilities to develop teaching materials significantly improved after participating in the project-based instruction $(\mathrm{p}=.000)$. Considering each performance criterion, the participants performed better on the post-test in all five criteria:

1) The post-test scores for the 'design' criterion $(M=4.00, S D=0.83)$ were significantly higher than the pre-test scores $(M=1.67, S D=0.48), t(29)=-26.655, p=.000$.

2) The post-test scores for the 'content relevance to the context and target learners' criterion $(\mathrm{M}=3.83, \mathrm{SD}=0.70)$ were significantly higher than the pre-test scores $(\mathrm{M}=$ $2.00, \mathrm{SD}=0.59), \mathrm{t}(29)=-26.492, \mathrm{p}=.000$.

3) The post-test scores for the 'encouraging student engagement in the learning process' criterion $(M=4.00, S D=0.59)$ were significantly higher than the pre-test scores $(\mathrm{M}=2.33, \mathrm{SD}=0.48), \mathrm{t}(29)=-19.039, \mathrm{p}=.000$.

4) The post-test scores for the 'content accuracy and appropriateness' criterion ( $M=$ $4.50, S D=0.51)$ were significantly higher than the pre-test scores $(M=2.67, S D=$ $0.48), t(29)=-14.367, p=.000$.

5) The post-test scores for the 'the integration of content, pedagogy, and technology' criterion $(M=4.33, S D=0.48)$ were significantly higher than the pre-test scores $(M=$ $2.00, \mathrm{SD}=0.00), \mathrm{t}(29)=-26.655, \mathrm{p}=.000$.

\section{Discussion and Conclusion}

The research results confirm the hypothesis, finding that after participating in the PjBL instruction, the pre-service Social Studies teachers achieved higher mean scores when measuring their ability to develop teaching materials. PjBL emerged from the constructivism learning theory and is an appropriate approach to improve pre-service Social Studies teachers' abilities to develop teaching materials. It can be concluded that the content taught in the Innovation in Social Studies Teaching course covers both knowledge and the practical knowledge application. The course is therefore wellcoordinated with the PjBL steps which aim to promote student-centered learning environments within which a culture of inquiry is created, and questions are a driving force of significant learning. In PjBL, questions are posed to create an inquiry-driven classroom where students are encouraged to be engaged and actively seek information. Consequently, students gain an in-depth and comprehensive 
understanding of the content. These findings are in agreement with Wilhelm and Sherrod (2008), Howard (2002), García (2016), and Özdamli (2011), who asserted that project-based learning is effective at helping pre-service teachers develop subjectmatter knowledge in addition to their knowledge application abilities, and technological pedagogical content knowledge (TPACK).

\section{References}

Bell, S. (2010). Project-based learning for the $21^{\text {st }}$ century: Skills for the future. The Clearing House, 83 , 39-43.

Canales, A., \& Maldonado, L. (2018). Teacher quality and student achievement in Chile: Linking teachers' contribution and observable characteristics. International Journal of Educational Development, 60, 33-50.

Cennamo, K., Ross, J., \& Ertmer, P. (2010). Technology integration for meaningful classroom use: A standard-based approach. Belmont, CA: Wadsworth, Cengage Learning.

Darling-Hammond, L. (2000). Teacher quality and student achievement: A review of state policy evidence. Education Policy Analysis Archives, 8(1). doi:https://doi.org/10.14507/epaa.v8n1.2000

García, C. (2016). Project-based learning in virtual groups: Collaboration and learning outcomes in a virtual training course for teachers. Procedia: Social and Behavioral Sciences, 228, 100-105.

Harris, J., Grandgenett, N., \& Hofer, M. (2010). Testing a TPACK-based technology integration assessment rubric, In Research highlights in technology and teacher education 2010, pp. 38333840. Chesapeake, VA: AACE.

Hofer, M., \& Grandgenett, N. (2012). TPACK development in teacher education: A longitudinal study of preservice teacher in a secondary M.A.ED. program. Journal of Research on Technology in Education, 45(1), 83-106.

Howard, J. (2002). Technology-enhanced project-based learning in teacher education: Addressing the goals of transfer. Journal of Technology and Teacher Education, 10(3), 343-364.

Koehler, M., \& Mishra, P. (2009). What is technological pedagogical content knowledge?. Contemporary Issues in Technology and Teacher Education, 9(1), 60-70.

Larmer, J., Mergendoller, J., \& Boss, S. (2010). Setting the standard for project-based learning: A proven approach to rigorous classroom instruction. Alexandria, VA: ASCD.

Lasauskiene, J., \& Rauduvaite, A. (2015). Project-based learning at university: Teaching experiences of lecturers. Procedia: Social and Behavioral Sciences, 197, 788-792.

Lyublinskaya, I., \& Tournaki, N. (2011). The effects of teacher content authoring on TPACK and on student achievement in algebra: Research on instruction with the TI-Nspire handheld, In Proceedings of Society for Information Technology and Teacher Education International Conference 2011, pp. 4396-4401. Chesapeake, VA: Association for the Advancement of Computing in Education.

Namwong, T. (2016). Learning development and project-based learning management to enhance creative graphic design project. Ph.D. in Social Sciences Journal, 6(3), 1-10.

Özdamli, F. (2011). The experiences of teacher candidates in developing instructional multimedia materials in project-based learning. Procedia: Social and Behavioral Sciences, 15, 3810-3820.

Payne, D. (2002). Applied educational assessment (2nd ed.). Belmont, CA: Wadsworth Thomson Learning.

Royal Society. (2015). The royal society dictionary of contemporary education. Bangkok: Office of the Royal Society. (in Thai) 
Saye, J. (2017). Disciplined inquiry in social studies classrooms, In The Wiley handbook of social studies research, pp. 336-359. Malden, MA: John Wiley \& Sons.

Schultz, B. (2010). Project-based curriculum, In Encyclopedia of curriculum studies, pp. 690-691. Thousand Oaks, CA: SAGE.

Stix, A., \& Hrbek, F. (2006). Teacher as classroom coaches: How to motivate students across the content areas. Alexandria, VA: ASCD.

The Teachers' Council of Thailand. (2015). Professional standards and ethics. Bangkok: The Teachers' Council of Thailand.

Wilhelm, J., Walters, K, \& Sherrod, S. (2008). Project-based learning environments: Challenging preservice teachers to act in the moment. The Journal of Educational Research, 101(4), 220-233. 